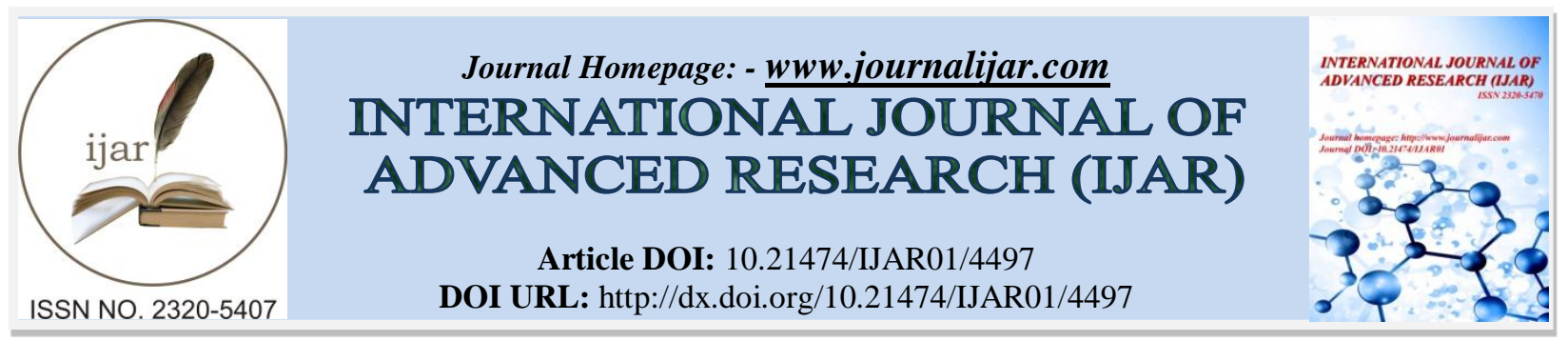

RESEARCH ARTICLE

\title{
EFFECT OF BIOLOGICAL ADDITIVES SUPPLEMENTATION ON SKIN AND COAT CHARACTERISTICS OF BARKI SHEEP.
}

Hekal Samia A.

Wool Production and Technology Dept., Desert Research Center, El-Matareya, Cairo, Egypt.

\section{Manuscript Info}

\section{Manuscript History}

Received: 16 April 2017

Final Accepted: 18 May 2017

Published: June 2017

Key words:-

ZADO, ZAD, Wool Follicle, Wool

traits, Barki sheep

\section{Abstract}

This study was planned to throw some lights on the effects of ZADO and ZAD as biological additives compounds with different doses on skin and coat characteristics of Barki sheep.

ZAD and ZADO as biological compounds are biotechnical solutions prepared from natural, multi/mix of the enzymes in addition to the related anaerobic bacteria. One hundred Barki ewes (2-3 years old and averaged $38.89 \pm 1.02 \mathrm{~kg}$ ) were assigned randomly into five equal groups (20 each). The $1^{\text {st }}$ group was severed as control group fed on concentrates feed mixture (CFM) without any additives while the $2^{\text {nd }}$ and $3^{\text {rd }}$ groups were fed the same CFM with 6 and $10 \mathrm{~g} / \mathrm{head} /$ day from ZADO, respectively. The $4^{\text {th }}$ and $5^{\text {th }}$ groups fed CFM with 6 and 10 $\mathrm{ml} / \mathrm{head} /$ day from ZAD, receptively. All groups were offered bean (Phaseolus vulgaris) straw ad libitum as a sole source of roughage.

The study revealed that both ZADO and ZAD treatments had affected significantly the internal diameter, wall thickness and fibre diameter of the primary follicles whereas the external diameter was not affected. Concerning the secondary follicles, there was a significant increase in the external diameter of the treated groups compared to control one. On the other hand, a high significant increase $(\mathrm{p}<0.01)$ were observed among the internal diameter and wall thickness in ZADO $6 \mathrm{gm}$ and ZAD $10 \mathrm{gm}$. The histochemical study demonstrated that the presence of general carbohydrates in both primary and secondary follicles indicated an increase of follicle activity especially in the ZADO groups with the increased dose (10gm vs. 6mg). In general proteins, the higher values of both primary and secondary follicles were found in control and ZAD $10 \mathrm{gm}$. While, the lowest one was reported for $\mathrm{ZAD} 6 \mathrm{gm}$.

ZADO $(10 \mathrm{mg})$ increased value of staple length, kemp fibre and medullated fibre and decrease fine fibre. While, ZAD (10 mg) produced a moderate value of staple length with increase of fine fibre percentage and decrease medullated fibre and kemp fibre percentage. Treated ZADO (6 mg) had lower Prickle factor (PF), while ZAD (10 $\mathrm{mg}$ ) had higher one.

In general, using ZADO or ZAD as feeding additives for sheep could improve wool follicles activity as well as wool quality and quantity as a final product with suitable characteristics for wool industry.

Corresponding Author:- Hekal Samia A.

Address:- Wool Production and Technology Dept., Desert Research Center, El-Matareya, Cairo, Egypt. 
Copy Right, IJAR, 2017,. All rights reserved.

\section{Introduction:-}

In the tropics and subtropics, the productivity of ruminant livestock is constrained by the shortage of good quality feed, especially during the long dry season (Raghuvansi et al., 2007). A lot of attempts have been carried out to search for low price and high quality feeds by using traditional and non-traditional products, among which; ZAD and ZADO products. They have been shown to improve ruminal fermentation, nitrogen balance, nutrient digestibility, feed conversion and body gain (Gado et al., 2007 and Salem et al., 2007 a \& b).

ZAD compound is a biotechnical solution prepared from natural, multi/mix of the enzymes cellulases (8.2u/gm), hemicellulases $(6.2 \mathrm{u} / \mathrm{gm})$, amylase $(64.4 \mathrm{u} / \mathrm{gm})$, and protease $(12.3 \mathrm{u} / \mathrm{gm})$. In addition to those enzymes ZAD contains the related anaerobic bacteria which produce same listed enzymes. ZADO compound is similar to ZAD but its enzyme contents are much higher per gm fed and contained Sacchromycescerevisiae yeast. ZADO was directly fed to animals just before feeding because its activity starts immediately in the rumen.

A commercial exogenous enzyme mixture (ZADO®), prepared from anaerobic bacterium, has been shown to improve ruminal fermentation, $\mathrm{N}$ balance and nutrient digestibility, (Gado et al., 2007; Soliman, 2006), Feeding enzymes is often accompanied by increased feed intake, which may partly due to increased palatability of the diet as sugars released by pre-ingestive fiber hydrolysis. However post-ingestive enzyme effects such as increased digestion rate and/or extent of digestion (Beauchemin and Rode, 1996; Feng et al.,1996; Gado and Salem, 2008; Krueger et al., 2008) may increase hydrolytic activity in the rumen to reduce gut fill and enhance feed intake (Adesogan, 2005).

Abd El-Aziz (2007) stated that the improvement of digestibility of ration supplemented by ZAD compound attributed to many factors, a) improvement in absorption during digestion by increasing the reactive surface areas of nutrients. b) improving feed utilization by slowing feed passage time out of the digestive tract which was reflected in better absorption. ZADO supplementation also increased rumen ammonia nitrogen and total short chain fatty acid concentration (Gado et al., 2009).

However, both of them have been shown to improve nutritional status of the animals but there is a lake of information's about their effects on wool follicles activity as well as wool production (quality and quantity). So, this study was planned to throw some lights on the effect of ZADO and ZAD as biological additives with different doses on skin and coat characteristics of Barki sheep.

\section{Materials and Methods:-}

The present study was carried out at Animal Production Research Unit at the Sustainable Development Center for Matrouh Resources(SDCMR),Matrouh Governorate, which belongs to the Desert Research Center (DRC), Ministry of Agricultural and Land Reclamation, Egypt.

\section{Animals and Management:-}

One hundred Barki ewes (2-3 years old and averaged $38.89 \pm 1.02 \mathrm{~kg}$ ) were assigned randomly into five equal groups (20 of each). The $1^{\text {st }}$ group was severed as control group fed on concentrates feed mixture (CFM) without any additives while the $2^{\text {nd }}$ and $3^{\text {rd }}$ groups were fed the same CFM with 6 and $10 \mathrm{~g} / \mathrm{head} /$ day from ZADO, respectively. The $4^{\text {th }}$ and $5^{\text {th }}$ groups were fed CFM with 6 and $10 \mathrm{ml} / \mathrm{head} /$ day from ZAD, receptively. All groups were offered bean (Phaseolus vulgaris) straw ad libitum as a sole source of roughage. Biological additives were mixed well with concentrate rations before feeding and rations were adjusted biweekly to cover their requirements during their different physiological status according to Kearl (1982). All groups were clinically healthy and free from internal and external parasites.

\section{Biological Additives:-}

For the biological additives, ZAD is a patent No. 22155 of Egyptian Official Authority; it was manufactured and produced according to the procedure of Gado (1997) in the molecular biology lab, Animal Production Department, Ain-Shams University, Cairo, Egypt. 


\section{Sampling and Measurements:-}

Skin samples were taken from the mid-side position from all animals by a curved scissor with a suitable depth to represent all skin layers.The skin samples were fixed on foam to get flattened in calcium formol for about 24 hours, and then washed and left for 24 hours in distilled water before moving them into $70 \%$ ethanol (Barker, 1958).

Skin specimens were then dehydrated in an ascending series of ethanol (30 minutes in each of 70\%, 80\% and 90\% ethanol and finally two changes each for 15 minutes in absolute ethanol). The specimens were cleared in benzene for about 30 minutes, infiltrated in paraffin wax of a melting point of $60^{\circ} \mathrm{C}$ ( 4 changes, 20 minutes each) and then embedded in the same paraffin to prepare the blocks. Transverse sections (6-8microns in thickness) were prepared for histological and histochemical studies. For general histological observations of the wool follicles and fibre diameters, skin sections were stained by Haematoxylin and Eosin stain (Drury and Wallington, 1980). For the histochemical investigations, Mercury Bromophenol blue according to Chapman(1975) was used for the demonstration of general proteins and Periodic acid Schiff's reaction was used for the detection of general carbohydrates (Mc-Manus and Cason, 1950)

Wool samples were taken from mid-side position as close as possible to the skin surface. Ten staples were taken randomly from each wool sample to measure staple length to the nearest $\mathrm{mm}$ using a ruler. Length measured from the bottom till the dense part of the staple. Five hundred fibers from each sample were used to calculate the average fiber diameter and its distribution percentage using a microscope and image captured by image analysis software (Zen 2012, Blue edition) and device (Carl Zeiss Micro-Imaging GmbH).

\section{Statistical Analysis:-}

Data were analyzed by the general linear model (GLM) procedure using SAS software (2004). Then, Duncan's multiple range test (Duncan, 1955) was used for detecting the significantly differences between means.

\section{Results and Discussion:-}

Barki sheep skin has two wool follicle types, primary and secondary. The primaries are usually the largest and found often three in the skin. While the secondaries are the smallest size, more numerous and lie on one side of the primaries (Fig. 1). The main difference between the primary and secondary follicles was the presence of both sweat and sebaceous glands and erector pili muscle accompanying the primary follicles while the secondaries have only the sebaceous glands.

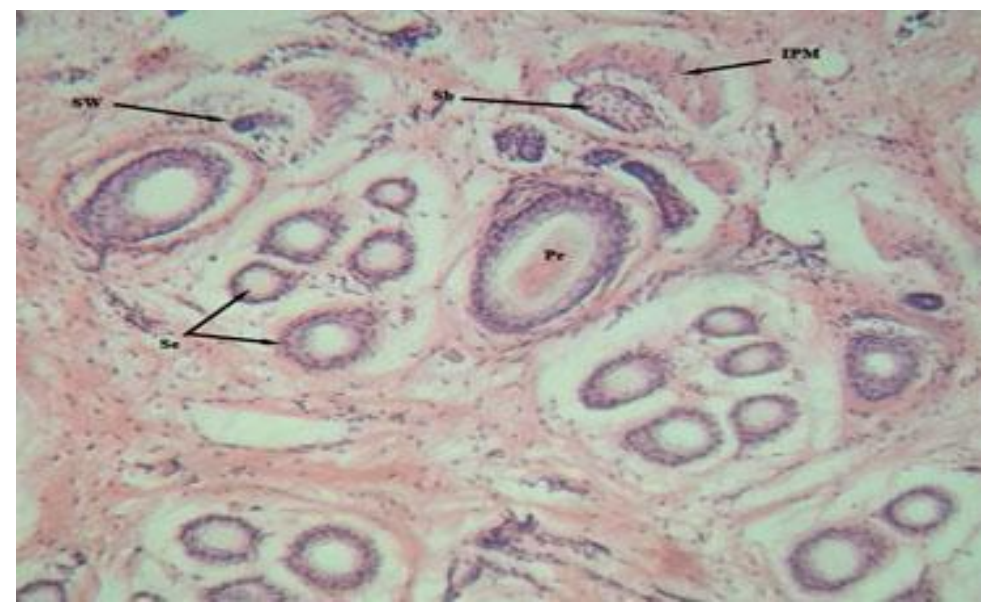

Fig 1:- Transverse section in skin of Barki sheep showing follicle group structures. EPM, erector pili muscle; $\operatorname{Pr}$, primary follicle; Sb, sebaceous gland; Sc, secondary follicle; Sw, sweat gland (X100).

The present results showed that both ZADO and ZAD treatments possessed a significant effect on the primary follicles (Table 1). The internal diameter $(78.60$ and 85.17 vs.74.89 $\mu$ ), wall thickness (84.04 and 78.22 vs. $72.36 \mu)$ and fibre diameter $(54.25$ and 61.03 vs. $55.94 \mu)$ were affected significantly $(\mathrm{P}<0.05)$ in treated groups compared to control group, respectively. While external diameter didn't affected significantly with the same treatments. 
Regardless, the type of biological treatments, doses levels(6 and $10 \mathrm{mg}$ ) had a significant effect on external (169.89and 171.93 vs. 147.25) and internal diameters (75.13and 95.64 vs. 74.89), wall thickness (94.75and 76.28 vs.72.36) and fibre diameter (47.33and 69.65 vs. 55.94.) compared to the control group, respectively.

Table (1)revealed that ZADO $(6 \mathrm{gm})$ and ZAD $(10 \mathrm{gm})$ had highly significant changes $(\mathrm{p}<0.01)$ in both external diameter and wall thickness of primary follicle with corresponding values $(187.50,190.66)$ and $(115.71,88.51)$, respectively. The internal diameter of the same follicles showed significant difference $(\mathrm{P}<0.05)$ between $\mathrm{ZADO}$ (10mg) and ZAD (10mg) with values being89.14and 102.14, respectively.

Concerning secondary follicles, the external diameter of the treated groups was significantly higher than their partners in the control one(Table2). The internal diameter as well as wall thickness were found to be affected $(\mathrm{P}<0.05)$ significantly due to dose level where ZADO $(6 \mathrm{gm})$ and ZAD $(10 \mathrm{gm})$ scored the highest values. Helal and fayed(2013)confirmed these results and stated that addition of cellulitic bacteria to Barki rams diet had higher effects on follicle dimensions values and suggested that these changes in the dimensions are the principal cause of variation in fibre output. They outlined that the rate-limiting step in wool production per follicle is the proliferative (i.e. cell division) phase and not keratinization (i.e.protein synthesis) phase of fibre formation.

Table (1) demonstrated that, groups supplemented with high level $(10 \mathrm{~g} / \mathrm{h} / \mathrm{d})$ either from ZADO or ZAD were greater in fiber diameter compared to their partners supplemented with the low level $(6 \mathrm{~g} / \mathrm{h} / \mathrm{d})$. Group with $10 \mathrm{~g} / \mathrm{h} / \mathrm{d}$ from $\mathrm{ZAD}$ had the highest fiber diameter among all studied groups. These results might be related to that wool influenced by the nutrients available to the wool follicle (Abdel-Salam, et al., 2014). Abdelaziz et al. (2000) cleared out that, better nutrients resulted in low grade and high diameter. Jafari et al. (2005)studied the effects of treated wheat straw with exogenous fibre-degrading enzymes (EFDE) on wool characteristics of ewe lambs and found that replacing 20\%, and 30\% of treated wheat straw with EFDE caused numerical increases in final wool diameter (34.40, and 34.89, respectively, vs. $30.49 \mu \mathrm{m})$ Also, feeding untreated wheat straw compared to alfalfa hay, tended to increase wool diameter (34.97 vs.30.49).

Anyhow, the changes in wool growth and characteristics are associated with quality and relative mixture of absorbed amino acids, adding fibrolytic enzymes to the diets, increased viable rumen bacteria (Nsereko et al. 2002), rate of ruminal bacteria growth and flow, then greater absorption of amino acids in small intestine, which would have significant impact on the supply of metabolizable protein to the animal. Reisetal. (1992) provided sheep with most of their nutrients as abomasal infusions, and found that the rate of wool growth was markedly altered by protein supply.

Table 1:- Means \pm SE of primary follicles dimensions $(\mu \mathrm{m})$ and their fiber diameters of the different experimental groups

\begin{tabular}{|c|l|l|l|l|l|}
\hline $\begin{array}{l}\text { Primary } \\
\text { follicles }\end{array}$ & \multicolumn{1}{|c|}{ Control } & \multicolumn{1}{|c|}{$6 \mathrm{Mg}$} & \multicolumn{1}{c|}{ Overall mean } \\
\hline \multirow{3}{*}{$\begin{array}{c}\text { External } \\
\text { diameter }\end{array}$} & Zado & $147.25 \pm 4.440$ & $187.50 \pm 4.440$ & $153.20 \pm 6.704$ & $162.65 \pm 3.061^{\mathrm{a}}$ \\
\cline { 2 - 6 } & Zad & $147.25 \pm 4.440$ & $152.28 \pm 5.925$ & $190.66 \pm 4.997$ & $163.40 \pm 2.977^{\mathrm{a}}$ \\
\cline { 2 - 6 } & Overall mean & $147.25 \pm 3.139^{\mathrm{b}}$ & $169.89 \pm 3.702^{\mathrm{a}}$ & $171.93 \pm 4.180^{\mathrm{a}}$ & \\
\hline \multirow{2}{*}{$\begin{array}{c}\text { Internal } \\
\text { diameter }\end{array}$} & Zado & $74.89 \pm 2.739$ & $71.78 \pm 2.739$ & $89.14 \pm 4.137$ & $78.60 \pm 1.889^{\mathrm{b}}$ \\
\cline { 2 - 6 } & Zad & $74.89 \pm 2.739$ & $78.48 \pm 3.656$ & $102.14 \pm 3.083$ & $85.17 \pm 1.837^{\mathrm{a}}$ \\
\cline { 2 - 6 } & Overall mean & $74.89 \pm 1.937^{\mathrm{b}}$ & $75.13 \pm 2.284^{\mathrm{b}}$ & $95.64 \pm 2.579^{\mathrm{a}}$ & \\
\hline \multirow{3}{*}{ Wall thickness } & Zado & $72.36 \pm 3.261$ & $115.71 \pm 3.261$ & $64.06 \pm 4.924$ & $84.04 \pm 2.248^{\mathrm{a}}$ \\
\cline { 2 - 6 } & Zad & $72.36 \pm 3.261$ & $73.79 \pm 4.352$ & $88.51 \pm 3.670$ & $78.22 \pm 2.187^{\mathrm{b}}$ \\
\cline { 2 - 6 } & Overall mean & $72.36 \pm 2.305^{\mathrm{c}}$ & $94.75 \pm 2.719^{\mathrm{a}}$ & $76.28 \pm 3.070^{\mathrm{b}}$ & \\
\hline \multirow{2}{*}{ Fibre diameter } & Zado & $55.94 \pm 2.437$ & $38.53 \pm 2.437$ & $68.27 \pm 3.680$ & $54.25 \pm 1.680^{\mathrm{b}}$ \\
\cline { 2 - 6 } & Zad & $55.94 \pm 2.437$ & $56.13 \pm 3.252$ & $71.02 \pm 2.743$ & $61.03 \pm 1.634^{\mathrm{a}}$ \\
\cline { 2 - 6 } & Overall mean & $55.94 \pm 1.723^{\mathrm{b}}$ & $47.33 \pm 2.032^{\mathrm{c}}$ & $69.65 \pm 2.295^{\mathrm{a}}$ & \\
\hline
\end{tabular}

Means with deferent letters in the same raw or column differ significantly at $\mathrm{p}<0.05$. 
Table 2:- Means $\pm \mathrm{SE}$ of secondary follicles dimensions $(\mu \mathrm{m})$ and their fiber diameters of the different experimental groups

\begin{tabular}{|c|c|c|c|c|c|}
\hline $\begin{array}{c}\text { Secondary } \\
\text { follicles }\end{array}$ & & Control & $6 \mathrm{Mg}$ & $10 \mathrm{Mg}$ & Overall mean \\
\hline \multirow{3}{*}{$\begin{array}{c}\text { External } \\
\text { diameter }\end{array}$} & Zado & $70.72 \pm 1.940$ & $88.33 \pm 2.264$ & $76.49 \pm 2.634$ & $78.51 \pm 1.326^{\mathrm{a}}$ \\
\cline { 2 - 6 } & Zad & $70.72 \pm 1.940$ & $78.97 \pm 3.051$ & $89.95 \pm 2.513$ & $79.88 \pm 1.468^{\mathrm{a}}$ \\
\cline { 2 - 6 } & Overall mean & $70.72 \pm 1.372^{\mathrm{b}}$ & $83.65 \pm 1.900^{\mathrm{a}}$ & $83.22 \pm 1.820^{\mathrm{a}}$ & \\
\hline \multirow{3}{*}{$\begin{array}{c}\text { Internal } \\
\text { diameter }\end{array}$} & Zado & $31.01 \pm 0.808$ & $27.11 \pm 0.944$ & $31.90 \pm 1.098$ & $30.00 \pm 0.552^{\mathrm{b}}$ \\
\cline { 2 - 6 } & Zad & $31.01 \pm 0.808$ & $32.57 \pm 1.272$ & $37.72 \pm 1.048$ & $33.77 \pm 0.612^{\mathrm{a}}$ \\
\cline { 2 - 6 } & Overall mean & $31.01 \pm 0.571^{\mathrm{b}}$ & $29.84 \pm 0.792^{\mathrm{c}}$ & $34.81 \pm 0.759^{\mathrm{a}}$ & \\
\hline \multirow{3}{*}{ Wall thickness } & Zado & $39.71 \pm 1.517$ & $61.22 \pm 1.771$ & $44.58 \pm 2.060$ & $48.50 \pm 1.037^{\mathrm{a}}$ \\
\cline { 2 - 6 } & Zad & $39.71 \pm 1.517$ & $46.39 \pm 2.387$ & $52.22 \pm 1.966$ & $46.11 \pm 1.148^{\mathrm{b}}$ \\
\cline { 2 - 6 } & Overall mean & $39.71 \pm 1.073^{\mathrm{c}}$ & $53.80 \pm 1.486^{\mathrm{a}}$ & $48.40 \pm 1.424^{\mathrm{b}}$ & \\
\hline \multirow{3}{*}{ Fibre diameter } & Zado & $21.997 \pm 0.741$ & $15.445 \pm 0.865$ & $23.98 \pm 1.006$ & $20.47 \pm 0.506^{\mathrm{b}}$ \\
\cline { 2 - 6 } & Zad & $21.99 \pm 0.741$ & $24.71 \pm 1.165$ & $27.14 \pm 0.960$ & $24.62 \pm 0.560^{\mathrm{a}}$ \\
\cline { 2 - 6 } & Overall mean & $21.99 \pm 0.524^{\mathrm{b}}$ & $20.08 \pm 0.725^{\mathrm{c}}$ & $25.56 \pm 0.695^{\mathrm{a}}$ & \\
\hline
\end{tabular}

Means with deferent letters in the same raw or column differ significantly at $\mathrm{p}<0.05$.

Carbohydrates are considered the sign of follicle activity according to the assumption of Montagna (1956) that the carbohydrates in the outer root sheath is the source of energy for protein synthesis during fibre growth.

Table 3:- Carbohydrates concentration (Means \pm SE) of primary and secondary follicles in both outer and inner root sheath.

\begin{tabular}{|c|c|c|c|c|c|c|}
\hline $\begin{array}{c}\text { General } \\
\text { Carbohydrates }\end{array}$ & & & Control & $6 \mathrm{Mg}$ & $10 \mathrm{Mg}$ & Overall mean \\
\hline \multirow{6}{*}{$\begin{array}{l}\text { Primary } \\
\text { follicles }\end{array}$} & \multirow[t]{3}{*}{ Outer } & Zado & $0.47 \pm 0.013$ & $0.53 \pm 0.013$ & $0.73 \pm 0.010$ & $0.58 \pm 0.007^{\mathrm{a}}$ \\
\hline & & $\mathrm{Zad}$ & $0.47 \pm 0.013$ & $0.56 \pm 0.009$ & $0.49 \pm 0.010$ & $0.51 \pm 0.006^{b}$ \\
\hline & & Overall mean & $0.47 \pm 0.009^{c}$ & $0.55 \pm 0.008^{b}$ & $0.61 \pm 0.007^{\mathrm{a}}$ & \\
\hline & \multirow[t]{3}{*}{ Inner } & Zado & $0.43 \pm 0.012$ & $0.48 \pm 0.012$ & $0.70 \pm 0.009$ & $0.54 \pm 0.006^{\mathrm{a}}$ \\
\hline & & $\mathrm{Zad}$ & $0.43 \pm 0.012$ & $0.49 \pm 0.008$ & $0.48 \pm 0.009$ & $0.47 \pm 0.005^{b}$ \\
\hline & & Overall mean & $0.43 \pm 0.008^{\mathrm{c}}$ & $0.49 \pm 0.007^{b}$ & $0.59 \pm 0.006^{\mathrm{a}}$ & \\
\hline \multirow{6}{*}{$\begin{array}{l}\text { Secondary } \\
\text { follicles }\end{array}$} & \multirow[t]{3}{*}{ Outer } & Zado & $0.52 \pm 0.012$ & $0.57 \pm 0.014$ & $0.65 \pm 0.010$ & $0.58 \pm 0.007^{\mathrm{a}}$ \\
\hline & & $\mathrm{Zad}$ & $0.52 \pm 0.012$ & $0.54 \pm 0.011$ & $0.54 \pm 0.011$ & $0.53 \pm 0.006^{b}$ \\
\hline & & Overall mean & $0.52 \pm 0.008^{c}$ & $0.55 \pm 0.009^{b}$ & $0.60 \pm 0.007^{\mathrm{a}}$ & \\
\hline & \multirow[t]{3}{*}{ Inner } & Zado & $0.44 \pm 0.011$ & $0.59 \pm 0.013$ & $0.63 \pm 0.009$ & $0.55 \pm 0.006^{\mathrm{a}}$ \\
\hline & & $\mathrm{Zad}$ & $0.44 \pm 0.011$ & $0.50 \pm 0.010$ & $0.52 \pm 0.010$ & $0.49 \pm 0.006^{b}$ \\
\hline & & Overall mean & $0.44 \pm 0.007^{\mathrm{c}}$ & $0.55 \pm 0.008^{b}$ & $0.57 \pm 0.007^{\mathrm{a}}$ & \\
\hline
\end{tabular}

Means with deferent letters in the same raw or column differ significantly at $\mathrm{p}<0.05$.

The presence of carbohydrates in both primary and secondary follicles showed an increase in follicle activity with both doses of ZADO (Table 3 andFig.2). Gado et al. (2009) stated that stimulation of rumen microbial numbers using enzymes could be referred to the increase of microbial biomass, which would provide more total polysaccharides activity to digest feedstuffs. The microbial treatment utilized soluble and structural carbohydrates (Abo Baker, 2012). The present results might be due to the mode of action of ZADO which, increased rumen ammonia nitrogen and total short chain fatty acid thus enhance the production of volatile fatty acids which is the source of energy (Gado, 2009). From another point of view, the improvement in fiber fraction digestibility as a result of biological treatment might be related to the effect of the cellulose enzyme which responsible for the stepwise hydrolysis of cellulose to glucose (Aziz, 2009). Added enzymes made the fermentation more gluconeogenic, and thereby improved the energetic efficiency of fermentation. This shift in short chain fatty acids (SCFA) proportions could increase precursor availability, and improve nutrient utilization possibly due to fermentation of sugars released by cell wall hydrolysis by enzymes (Eun et al., 2007). This agrees with Dawson and Tricarico(1999) and Krueger and Adesogan (2008), who noted that enzyme mixtures containing cellulose were more inclined to alter the relative proportions of SCFA thereby resulting in more acetate and less propionate and butyrate. 


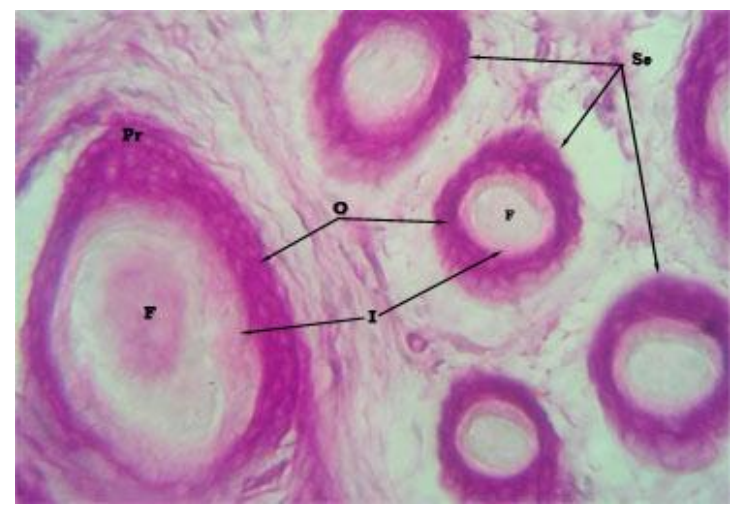

Fig 2:- Transverse section in the wool follicles of Barki sheep stained with PAS method showing the distribution of general carbohydrates in the different follicle sheaths. I, inner root sheath; O, outer root sheath; Pr, primary follicle; Sc, secondary follicle (X400).

Table 4:- Means of primary and secondary follicles general proteins concentrate in both outer and inner root sheath.

\begin{tabular}{|c|c|l|c|c|c|c|}
\hline $\begin{array}{c}\text { General } \\
\text { protein }\end{array}$ & & Control & $6 \mathrm{Mg}$ & $10 \mathrm{Mg}$ & Overall mean \\
\hline \multirow{3}{*}{$\begin{array}{c}\text { Primary } \\
\text { follicles }\end{array}$} & \multirow{2}{*}{ Outer } & Zado & $0.75 \pm 0.021$ & $0.64 \pm 0.009$ & $0.63 \pm 0.015$ & $0.67 \pm 0.009^{\mathrm{b}}$ \\
\cline { 3 - 6 } & & Zad & $0.75 \pm 0.021$ & $0.64 \pm 0.012$ & $0.71 \pm 0.012$ & $0.70 \pm 0.009^{\mathrm{a}}$ \\
\cline { 3 - 6 } & & Overall mean & $0.75 \pm 0.015^{\mathrm{a}}$ & $0.64 \pm 0.007^{\mathrm{c}}$ & $0.67 \pm 0.009^{\mathrm{b}}$ & \\
\cline { 3 - 7 } & Inner & Zado & $0.68 \pm 0.019$ & $0.64 \pm 0.008$ & $0.59 \pm 0.013$ & $0.64 \pm 0.008^{\mathrm{a}}$ \\
\cline { 3 - 6 } & & Zad & $0.68 \pm 0.019$ & $0.59 \pm 0.011$ & $0.67 \pm 0.011$ & $0.65 \pm 0.008^{\mathrm{a}}$ \\
\cline { 3 - 7 } & Overall mean & $0.68 \pm 0.013^{\mathrm{a}}$ & $0.61 \pm 0.007^{\mathrm{b}}$ & $0.63 \pm 0.009^{\mathrm{b}}$ & \\
\hline \multirow{3}{*}{$\begin{array}{c}\text { Secondary } \\
\text { follicles }\end{array}$} & \multirow{2}{*}{ Outer } & Zado & $0.78 \pm 0.012$ & $0.61 \pm 0.009$ & $0.75 \pm 0.022$ & $0.71 \pm 0.009^{\mathrm{a}}$ \\
\cline { 3 - 7 } & & Zad & $0.78 \pm 0.012$ & $0.56 \pm 0.011$ & $0.61 \pm 0.0128$ & $0.65 \pm 0.007^{\mathrm{b}}$ \\
\cline { 3 - 7 } & Overall mean & $0.78 \pm 0.009^{\mathrm{a}}$ & $0.59 \pm 0.007^{\mathrm{c}}$ & $0.68 \pm 0.012^{\mathrm{b}}$ & \\
\cline { 3 - 7 } & \multirow{2}{*}{ Inner } & Zado & $0.75 \pm 0.012$ & $0.60 \pm 0.009$ & $0.73 \pm 0.021$ & $0.69 \pm 0.008^{\mathrm{a}}$ \\
\cline { 3 - 7 } & & Zad & $0.75 \pm 0.012$ & $0.49 \pm 0.010$ & $0.61 \pm 0.012$ & $0.62 \pm 0.006^{\mathrm{b}}$ \\
\cline { 3 - 7 } & & Overall mean & $0.75 \pm 0.008^{\mathrm{a}}$ & $0.54 \pm 0.007^{\mathrm{c}}$ & $0.67 \pm 0.012^{\mathrm{b}}$ & \\
\hline
\end{tabular}

Means with deferent letters in the same raw or column differ significantly at $\mathrm{p}<0.05$.

The distribution of the general proteins as demonstrated by the bromophenol blue stain in wool follicles of the different groups showed that both outer and inner root sheaths of the wool follicles possessed high amounts of proteins (Table 4). The higher values of general proteins in the outer root sheath of primary follicles were found to be $0.75 \pm 0.021$ and $0.71 \pm 0.012$ for control and ZAD $10 \mathrm{gm}$, respectively (Table 4). While the lowest one was reported for ZAD $6 \mathrm{gm}$. The same trend was found in the outer and inner root sheaths of secondary follicles (Table 4 and Fig

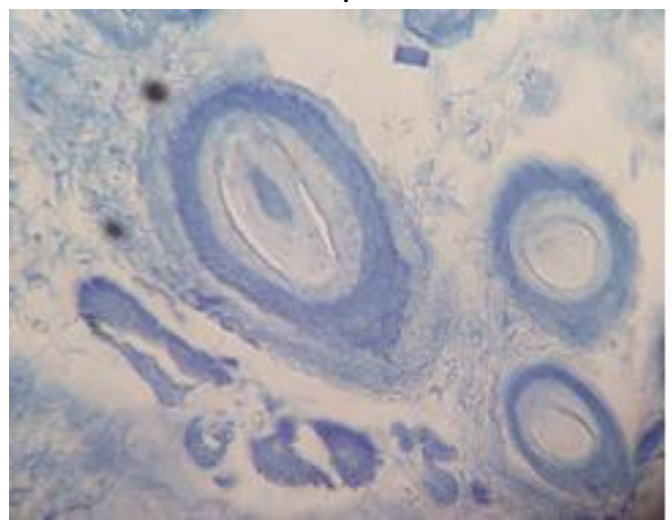

Fig 3:- Transverse section in the wool follicles of Barki ewes stained with bromophenol blue showing the distribution of general proteins in the different follicle sheaths. I, inner root sheath; O, outer root sheath; Pr, primary follicle; Sc, secondary follicle (X400) 
ZADO contains some specific enzymes such as protease that induces protein catabolism by hydrolysis of the peptide bonds that link amino acids together in the polypeptide chain forming the protein, which absorbed through the intestinal wall. Ado et al. (2009) found that addition of enzymes increased rumen microbial N synthesis.

In primary follicles, the total amount of general proteins was varied significantly between ZADO and ZAD with values being $0.67 \pm 0.009$ and $0.70 \pm 0.009$ in outer root sheath, respectively. Meanwhile, the secondary follicles showed a reversible trend which was $0.71 \pm 0.009$ and $0.65 \pm 0.007,0.69 \pm 0.008$ and $0.62 \pm 0.006$ for outer and inner root sheaths, respectively. Animals in $\mathrm{ZAD}(10 \mathrm{gm})$ group showed the highest $(\mathrm{P}<0.05)$ protein contents in the outer and inner root sheaths of the primary follicles $(0.71 \pm 0.012$ and $0.67 \pm 0.011)$ respectively. Elmostafa, (2013) reported that ZADO improved significantly total protein. However, Helal and Fayed (2013) found that cellulytic bacteria had insignificant effect on the protein contents of the outer and inner root sheaths. In Mohair production many authors illustrated that nutrition was a major determinant of follicle activity (McGregor, 1988; Doyle et al., 1995 and Scobie et al., 1998).

Generally, the application of exogenous enzymes to the diets of small ruminants has had little impact on production performance. Miller fed a barley-based diet treated with a commercial exogenous enzyme to Dorset-cross ewe lambs and observed no effects on wool growth.

Results demonstrated that using both ZADO and ZAD, with two doses (6 and $10 \mathrm{mg} / \mathrm{h} /$ day)had a significant effect on wool characteristics especially staple length (Table 5). Animals fed ZADO (10 mg) recorded higher value of staple length $(10.73 \pm 0.355 \mathrm{~cm})$ with lowest value of fine fibre diameter percentage $(83.92 \pm 2.197)$, higher value of medullated fibre percentage $(15.09 \pm 1.992)$ and kemp fibre percentage $(0.97 \pm 0.438)$. Ten mg ZAD produced a moderate value of staple length $(8.17 \pm 0.375)$ with higher value of fine fibre diameter percentage $(90.43 \pm 2.197)$, lowest value of medullated fibre percentage $(9.13 \pm 1.992)$ and kemp fibre percentage $(0.42 \pm 0.438)$. Abdou, et al. (2016) in sheep feeding propionbacteria, reported increase in wool production as a result of increasing both fibre diameter and staple length and this was in accordance with (Abdel-Salam et al., 2014)

Table 5:- Least squares means \pm SE of fibre diameter, staple length, fine fibre $\%$, coarse fibre $\%$ and kempfibre $\%$.

\begin{tabular}{|c|c|c|c|c|c|}
\hline & & Control & $6 \mathrm{Mg}$ & $10 \mathrm{Mg}$ & Overall mean \\
\hline \multirow{3}{*}{$\begin{array}{l}\text { Staple length } \\
\text { (cm) }\end{array}$} & Zado & $5.88 \pm 0.375$ & $6.82 \pm 0.375$ & $10.73 \pm 0.355$ & $7.81 \pm 0.213^{\mathrm{a}}$ \\
\hline & Zad & $5.88 \pm 0.375$ & $8.50 \pm 0.400$ & $8.17 \pm 0.375$ & $7.51 \pm 0.221^{\mathrm{a}}$ \\
\hline & Overall mean & $5.88 \pm 0.265^{\mathrm{c}}$ & $7.66 \pm 0.274^{b}$ & $9.45 \pm 0.258^{\mathrm{a}}$ & \\
\hline \multirow[t]{3}{*}{ Fine fibre $(\%)$} & Zado & $89.42 \pm 2.197$ & $88.80 \pm 2.197$ & $83.92 \pm 2.197$ & $87.38 \pm 1.268^{\mathrm{a}}$ \\
\hline & Zad & $89.42 \pm 2.197$ & $86.45 \pm 2.197$ & $90.43 \pm 2.197$ & $88.77 \pm 1.268^{\mathrm{a}}$ \\
\hline & Overall mean & $89.42 \pm 1.553^{\mathrm{a}}$ & $87.63 \pm 1.553^{\mathrm{a}}$ & $87.18 \pm 1.553^{\mathrm{a}}$ & \\
\hline \multirow{3}{*}{$\begin{array}{l}\text { Medullated } \\
\text { fibre }(\%)\end{array}$} & Zado & $9.82 \pm 1.992$ & $10.65 \pm 1.992$ & $15.09 \pm 1.992$ & $11.85 \pm 1.150^{\mathrm{a}}$ \\
\hline & $\mathrm{Zad}$ & $9.82 \pm 1.992$ & $13.22 \pm 1.992$ & $9.13 \pm 1.992$ & $10.72 \pm 1.150^{\mathrm{a}}$ \\
\hline & Overall mean & $9.82 \pm 1.408^{\mathrm{a}}$ & $11.93 \pm 1.408^{\mathrm{a}}$ & $12.11 \pm 1.408^{\mathrm{a}}$ & \\
\hline \multirow[t]{3}{*}{ Kemp (\%) } & Zado & $0.74 \pm 0.438$ & $0.53 \pm 0.438$ & $0.97 \pm 0.438$ & $0.75 \pm 0.253^{\mathrm{a}}$ \\
\hline & Zad & $0.74 \pm 0.438$ & $0.32 \pm 0.438$ & $0.42 \pm 0.438$ & $0.50 \pm 0.253^{\mathrm{a}}$ \\
\hline & Overall mean & $0.74 \pm 0.310^{\mathrm{a}}$ & $0.43 \pm 0.310^{\mathrm{a}}$ & $0.70 \pm 0.310^{\mathrm{a}}$ & \\
\hline
\end{tabular}

Fineness of wool fibre has long been recognized as an important factor in evaluating sheep fleeces (Sharaf El-din and Ghoneim, 1963).As stated by Wilson (1940), fiber diameter is the basic trait for determining wool quality. Quality increases as wool becomes finer in diameter. Thus, the trait and its distribution were given more attention. Using ZADO in feeding produced finer fibre (25.28 and 27.56) than that obtained from sheep feeding with ZAD (28.18 and 29.62) at level $6 \mathrm{mg}$ and $10 \mathrm{mg}$, respectively. Also, all treated groups were finer than control (Table, 6).

Mean fibre diameter is considered as a very important factor in determining spinning performance and fabric properties including skin comfort. Meanwhile, the over width of the fibre diameter distribution, measured either as standard deviation or coefficient of variation, also has an effect on both spinning and skin comfort (de Groot, 1992, Lamb, 1992 and Naylor, et al., 1995).

Prickle factor is a term generally used to indicate the frequency of fibres at the coarse end of the fibre diameter distribution (Phillips et al. 1991). In table (6) Prickle factor (PF) which defined as the percentage of fibres with 
diameters exceeding $30 \mu \mathrm{m}$ from the total number of fibres indicated that the highest value of PF was found in ZAD (10 mg), while ZAD (6 mg) was the lowest one. To improve skin comfort it is thus expedient to concentrate on reducing Prickle factor. During wearing these coarse fibre ends press hard enough against the skin before buckling to trigger nerve ends lying just below the skin surface (Naylor, 2000). In this respect, the contribution of synthetic fibres in wool blends to obtain expected properties of performance, comfort, and handle has become more important (Onderet al., 2003). ZAD (6 mg) had the highest amount of fibreswithfibre diameter more than $42 \mathrm{~m} \mu(14.6 \%)$ of total fibres which is really huge unless it has low Prickle factor.

Table 6:- Fibre diameter subclasses, their percentage, means, standard deviations and coefficients of variation of wool clipped from sheep in different treatments, in comparison with the spinning count system.

\begin{tabular}{|c|c|c|c|c|c|c|c|c|c|c|c|c|c|c|c|c|c|c|c|c|c|c|}
\hline \multirow{2}{*}{$\begin{array}{c}\text { Typ } \\
\text { e of } \\
\text { woo } \\
\text { l }\end{array}$} & \multirow{2}{*}{$\begin{array}{c}\text { Spin } \\
\text { ning } \\
\text { coun } \\
t+\end{array}$} & \multirow{2}{*}{$\begin{array}{l}\text { Subc } \\
\text { lass" }\end{array}$} & \multicolumn{4}{|c|}{ Control } & \multicolumn{4}{|c|}{ ZADO 6mg } & \multicolumn{4}{|c|}{ ZADO 10mg } & \multicolumn{4}{|c|}{ ZAD 6mg } & \multicolumn{4}{|c|}{ ZAD 10mg } \\
\hline & & & $\%$ & $\mathbf{M}$ & \begin{tabular}{|l} 
S \\
$\mathbf{D}$
\end{tabular} & $\begin{array}{l}\text { C } \\
\text { V }\end{array}$ & $\%$ & $\mathbf{M}$ & \begin{tabular}{|l|} 
S \\
D
\end{tabular} & $\begin{array}{l}\mathbf{C} \\
\mathbf{V}\end{array}$ & $\%$ & $\mathbf{M}$ & \begin{tabular}{|l|}
$\mathbf{S}$ \\
$\mathbf{D}$
\end{tabular} & $\begin{array}{l}\mathbf{C} \\
\mathbf{V}\end{array}$ & $\%$ & $\mathbf{M}$ & \begin{tabular}{|l|} 
S \\
D
\end{tabular} & $\begin{array}{l}\mathbf{C} \\
\mathbf{V}\end{array}$ & & M & \begin{tabular}{|l} 
S \\
D
\end{tabular} & $\begin{array}{l}\text { C } \\
\text { V }\end{array}$ \\
\hline \multirow[t]{6}{*}{ Fine } & \multirow{3}{*}{$\begin{array}{c}\text { Fine } \\
\mathbf{r} \\
\text { than } \\
\mathbf{8 0 s}\end{array}$} & $<=10$ & 0. & $\begin{array}{c}8.8 \\
6\end{array}$ & $\begin{array}{c}1.1 \\
0\end{array}$ & $\begin{array}{l}12 . \\
37\end{array}$ & $\begin{array}{l}0 . \\
9\end{array}$ & $\begin{array}{c}9.3 \\
8\end{array}$ & $\begin{array}{l}\text { 0. } \\
54\end{array}$ & $\begin{array}{c}5.8 \\
1\end{array}$ & 0. & $\begin{array}{c}8.2 \\
3\end{array}$ & $\begin{array}{c}2.1 \\
9\end{array}$ & $\begin{array}{l}26 . \\
65\end{array}$ & o. & $\begin{array}{c}9.6 \\
7\end{array}$ & $\begin{array}{c}0.2 \\
2\end{array}$ & \begin{tabular}{|c|}
2.2 \\
5
\end{tabular} & 0. & 9.73 & - & - \\
\hline & & $\begin{array}{c}>10 \\
<=12\end{array}$ & $\begin{array}{l}0 . \\
5\end{array}$ & $\begin{array}{l}11 . \\
45\end{array}$ & $\begin{array}{c}0.0 \\
9\end{array}$ & $\begin{array}{c}0.7 \\
5\end{array}$ & 1. & $\begin{array}{l}11 . \\
20\end{array}$ & $\begin{array}{l}\mathbf{0 .} \\
\mathbf{3 9}\end{array}$ & \begin{tabular}{|c|}
3.4 \\
5
\end{tabular} & $\begin{array}{l}0 . \\
7\end{array}$ & $\begin{array}{l}11 . \\
18\end{array}$ & $\begin{array}{c}0.4 \\
7\end{array}$ & \begin{tabular}{|c|}
4.1 \\
6
\end{tabular} & $\begin{array}{l}2 . \\
1\end{array}$ & $\begin{array}{l}11 . \\
26\end{array}$ & $\begin{array}{c}0.5 \\
2\end{array}$ & $\begin{array}{c}4.6 \\
5\end{array}$ & $\begin{array}{l}0 . \\
4\end{array}$ & $\begin{array}{c}11.0 \\
2\end{array}$ & $\begin{array}{c}0 . \\
55\end{array}$ & $\begin{array}{c}5.0 \\
0\end{array}$ \\
\hline & & $\begin{array}{c}>12 \\
<=14\end{array}$ & 1. & 12. & $\begin{array}{c}0.7 \\
1\end{array}$ & $\begin{array}{c}5.5 \\
0\end{array}$ & $\begin{array}{l}3 . \\
1\end{array}$ & $\begin{array}{l}13 . \\
33\end{array}$ & $\begin{array}{c}0 . \\
50\end{array}$ & $\begin{array}{c}3.7 \\
6\end{array}$ & $\begin{array}{l}3 . \\
4\end{array}$ & $\begin{array}{l}13 . \\
30\end{array}$ & $\begin{array}{c}0.5 \\
8\end{array}$ & \begin{tabular}{|c|}
4.3 \\
3
\end{tabular} & $\begin{array}{l}6 . \\
9\end{array}$ & $\begin{array}{l}12 . \\
97\end{array}$ & $\begin{array}{c}0.6 \\
1\end{array}$ & $\begin{array}{c}4.7 \\
0\end{array}$ & 7. & $\begin{array}{c}13.1 \\
3\end{array}$ & $\begin{array}{l}\text { 0. } \\
57\end{array}$ & $\begin{array}{c}4.3 \\
1\end{array}$ \\
\hline & $80 \mathrm{~s}$ & $\begin{array}{c}>14 \\
<=16\end{array}$ & $\begin{array}{l}2 . \\
0\end{array}$ & 15. & $\begin{array}{c}0.2 \\
2\end{array}$ & $\begin{array}{c}1.4 \\
6\end{array}$ & $\begin{array}{l}4 . \\
9\end{array}$ & $\begin{array}{l}15 . \\
18\end{array}$ & $\begin{array}{l}\mathbf{0 .} \\
\mathbf{3 7}\end{array}$ & $\begin{array}{c}2.4 \\
4\end{array}$ & $\begin{array}{l}5 . \\
2\end{array}$ & $\begin{array}{l}15 . \\
16\end{array}$ & $\begin{array}{c}0.3 \\
6\end{array}$ & \begin{tabular}{|c|}
2.3 \\
5
\end{tabular} & $\begin{array}{l}8 . \\
2\end{array}$ & 15. & $\begin{array}{c}0.5 \\
2\end{array}$ & $\begin{array}{c}3.4 \\
7\end{array}$ & 2. & $\begin{array}{c}15.1 \\
1\end{array}$ & $\begin{array}{l}0 . \\
47\end{array}$ & $\begin{array}{c}3.1 \\
1\end{array}$ \\
\hline & $70 \mathrm{~s}$ & $\begin{array}{l}>16 \\
<=18\end{array}$ & 5. & 17. & $\begin{array}{c}0.5 \\
2\end{array}$ & $\begin{array}{c}2.9 \\
9\end{array}$ & $\begin{array}{r}12 \\
2\end{array}$ & 17. & $\begin{array}{l}0 . \\
57\end{array}$ & $\begin{array}{c}3.3 \\
5\end{array}$ & 10 & 17. & $\begin{array}{c}0.5 \\
2\end{array}$ & $\begin{array}{c}3.0 \\
6\end{array}$ & 7. & 17. & $\begin{array}{c}0.5 \\
7\end{array}$ & $\begin{array}{c}3.3 \\
3\end{array}$ & 4. & $\begin{array}{c}17.0 \\
1\end{array}$ & $\begin{array}{l}0 . \\
57\end{array}$ & $\begin{array}{c}3.3 \\
4\end{array}$ \\
\hline & $64 s$ & $\begin{array}{c}>18 \\
<=20\end{array}$ & $\begin{array}{l}9 . \\
1\end{array}$ & 19. & $\begin{array}{c}0.4 \\
7\end{array}$ & \begin{tabular}{|c|}
2.4 \\
3
\end{tabular} & $\begin{array}{l}13 \\
.5\end{array}$ & 18. & $\begin{array}{l}0 . \\
54\end{array}$ & $\begin{array}{c}2.8 \\
4\end{array}$ & $\begin{array}{l}9 . \\
8\end{array}$ & 19. & $\begin{array}{c}0.4 \\
9\end{array}$ & $\begin{array}{c}2.5 \\
9\end{array}$ & 7. & $\begin{array}{l}19 . \\
09\end{array}$ & $\begin{array}{c}0.5 \\
0\end{array}$ & $\begin{array}{c}2.6 \\
1\end{array}$ & 5. & $\begin{array}{c}18.9 \\
9\end{array}$ & $\begin{array}{l}0 . \\
45\end{array}$ & $\begin{array}{c}2.3 \\
7\end{array}$ \\
\hline \multirow[t]{6}{*}{$\begin{array}{l}\text { Med } \\
\text { ium }\end{array}$} & $62 \mathrm{~s}$ & $\begin{array}{c}>20 \\
<=22\end{array}$ & $\begin{array}{l}8 . \\
7\end{array}$ & 20. & $\begin{array}{c}0.4 \\
7\end{array}$ & $\begin{array}{c}2.2 \\
3\end{array}$ & $\begin{array}{c}12 \\
.5\end{array}$ & $\begin{array}{l}20 . \\
92\end{array}$ & $\begin{array}{l}0 . \\
46\end{array}$ & $\begin{array}{c}2.1 \\
8\end{array}$ & $\begin{array}{l}11 \\
.6\end{array}$ & $\begin{array}{l}20 . \\
96\end{array}$ & $\begin{array}{c}0.4 \\
9\end{array}$ & \begin{tabular}{|c|}
2.3 \\
3
\end{tabular} & 7. & $\begin{array}{l}20 . \\
91\end{array}$ & $\begin{array}{c}0.4 \\
9\end{array}$ & $\begin{array}{c}2.3 \\
3\end{array}$ & 6. & $\begin{array}{c}21.0 \\
1\end{array}$ & $\begin{array}{l}0 . \\
48\end{array}$ & $\begin{array}{c}2.2 \\
7\end{array}$ \\
\hline & 60s & $\begin{array}{c}>22 \\
<=24\end{array}$ & $\begin{array}{l}11 \\
.1\end{array}$ & $\begin{array}{l}22 . \\
91\end{array}$ & $\begin{array}{c}0.4 \\
8\end{array}$ & $\begin{array}{c}2.0 \\
8\end{array}$ & $\begin{array}{l}11 \\
.7\end{array}$ & $\begin{array}{l}22 . \\
91\end{array}$ & $\begin{array}{l}0 . \\
\mathbf{4 3}\end{array}$ & $\begin{array}{c}1.8 \\
9\end{array}$ & $\begin{array}{l}9 . \\
5\end{array}$ & 22. & $\begin{array}{c}0.4 \\
6\end{array}$ & $\begin{array}{c}2.0 \\
0\end{array}$ & $\begin{array}{l}7 . \\
3\end{array}$ & $\begin{array}{l}23 . \\
02\end{array}$ & $\begin{array}{c}0.4 \\
8\end{array}$ & $\begin{array}{c}2.0 \\
6\end{array}$ & $\begin{array}{l}8 . \\
2\end{array}$ & $\begin{array}{c}23.0 \\
1\end{array}$ & $\begin{array}{l} \\
44\end{array}$ & $\begin{array}{c}1.9 \\
2\end{array}$ \\
\hline & $58 \mathrm{~s}$ & $\begin{array}{c}>24 \\
<=26\end{array}$ & $\begin{array}{l}11 \\
.9\end{array}$ & 24. & $\begin{array}{c}0.5 \\
8\end{array}$ & $\begin{array}{c}2.3 \\
0\end{array}$ & $\begin{array}{l}8 . \\
8\end{array}$ & $\begin{array}{l}24 . \\
95\end{array}$ & $\begin{array}{c}\mathbf{0 .} \\
53\end{array}$ & $\begin{array}{c}2.1 \\
1\end{array}$ & 9. & $\begin{array}{l}24 . \\
97\end{array}$ & $\begin{array}{c}0.5 \\
7\end{array}$ & $\begin{array}{c}2.3 \\
0\end{array}$ & $\begin{array}{l}8 . \\
9\end{array}$ & $\begin{array}{l}24 . \\
90\end{array}$ & $\begin{array}{c}0.6 \\
1\end{array}$ & $\begin{array}{c}2.4 \\
3\end{array}$ & 9. & $\begin{array}{c}25.0 \\
1\end{array}$ & $\begin{array}{l}. \\
63\end{array}$ & $\begin{array}{c}2.5 \\
2\end{array}$ \\
\hline & $56 s$ & $\begin{array}{c}>26 \\
<=28\end{array}$ & $\begin{array}{l}6 . \\
8\end{array}$ & $\begin{array}{l}26 . \\
98\end{array}$ & $\begin{array}{c}0.3 \\
9\end{array}$ & $\begin{array}{c}1.4 \\
3\end{array}$ & $\begin{array}{l}4 . \\
8\end{array}$ & $\begin{array}{l}26 . \\
90\end{array}$ & $\begin{array}{l}\mathbf{0 .} \\
\mathbf{3 1}\end{array}$ & $\begin{array}{c}1.1 \\
6\end{array}$ & $\begin{array}{l}6 . \\
2\end{array}$ & $\begin{array}{l}26 . \\
83\end{array}$ & $\begin{array}{c}0.3 \\
6\end{array}$ & $\begin{array}{c}1.3 \\
3\end{array}$ & 4. & $\begin{array}{l}26 . \\
97\end{array}$ & $\begin{array}{c}0.4 \\
0\end{array}$ & $\begin{array}{c}1.4 \\
7\end{array}$ & $\begin{array}{l}7 . \\
3\end{array}$ & $\begin{array}{c}26.9 \\
5\end{array}$ & $\begin{array}{l} \\
42\end{array}$ & $\begin{array}{c}1.5 \\
6\end{array}$ \\
\hline & $54 \mathrm{~s}$ & $\begin{array}{c}>28 \\
<=30\end{array}$ & 7. & $\begin{array}{l}28 . \\
82\end{array}$ & $\begin{array}{c}0.5 \\
5\end{array}$ & $\begin{array}{c}1.9 \\
2\end{array}$ & $\begin{array}{l}5 . \\
2\end{array}$ & 28. & $\begin{array}{l}0 . \\
46\end{array}$ & $\begin{array}{c}1.5 \\
9\end{array}$ & 6. & \begin{tabular}{|l|}
28. \\
84
\end{tabular} & $\begin{array}{c}0.5 \\
4\end{array}$ & $\begin{array}{c}1.8 \\
7\end{array}$ & $\begin{array}{l}5 . \\
9\end{array}$ & $\begin{array}{l}28 . \\
77\end{array}$ & $\begin{array}{c}0.5 \\
3\end{array}$ & $\begin{array}{c}1.8 \\
5\end{array}$ & $\begin{array}{l}1 \\
0 .\end{array}$ & $\begin{array}{c}28.9 \\
0\end{array}$ & $\begin{array}{l}\text { 0. } \\
59\end{array}$ & $\begin{array}{c}2.0 \\
5\end{array}$ \\
\hline & $50 \mathrm{~s}$ & $\begin{array}{c}>30 \\
<=32\end{array}$ & 4. & $\begin{array}{l}30 . \\
80\end{array}$ & $\begin{array}{c}0.4 \\
8\end{array}$ & $\begin{array}{c}1.5 \\
6\end{array}$ & 2. & $\begin{array}{l}30 . \\
90\end{array}$ & $\begin{array}{l}0 . \\
52\end{array}$ & $\begin{array}{c}1.6 \\
9\end{array}$ & $\begin{array}{l}3 . \\
9\end{array}$ & $\begin{array}{l}30 . \\
82\end{array}$ & $\begin{array}{c}0.5 \\
\mathbf{3}\end{array}$ & $\begin{array}{c}1.7 \\
1\end{array}$ & $\begin{array}{l}5 . \\
4\end{array}$ & $\begin{array}{l}30 . \\
87\end{array}$ & $\begin{array}{c}0.5 \\
4\end{array}$ & $\begin{array}{c}1.7 \\
4\end{array}$ & $\begin{array}{l}6 . \\
8\end{array}$ & $\begin{array}{c}30.8 \\
6\end{array}$ & $\begin{array}{l}0 . \\
56\end{array}$ & $\begin{array}{c}1.8 \\
2\end{array}$ \\
\hline \multirow[t]{5}{*}{$\begin{array}{l}\text { Coa } \\
\text { rse }\end{array}$} & $48 s$ & $\begin{array}{c}>32 \\
<=34\end{array}$ & $\begin{array}{l}4 . \\
6\end{array}$ & $\begin{array}{l}32 . \\
87\end{array}$ & $\begin{array}{c}0.5 \\
7\end{array}$ & $\begin{array}{c}1.7 \\
4\end{array}$ & 2. & $\begin{array}{l}32 . \\
83\end{array}$ & $\begin{array}{l}0 . \\
52\end{array}$ & $\begin{array}{c}1.5 \\
9\end{array}$ & $\begin{array}{l}1 . \\
9\end{array}$ & $\begin{array}{l}32 . \\
79\end{array}$ & $\begin{array}{c}0.5 \\
2\end{array}$ & $\begin{array}{c}1.5 \\
8\end{array}$ & $\begin{array}{l}4 . \\
0\end{array}$ & $\begin{array}{l}32 . \\
85\end{array}$ & $\begin{array}{c}0.6 \\
0\end{array}$ & $\begin{array}{c}1.8 \\
4\end{array}$ & $\begin{array}{l}1 \\
0 . \\
2\end{array}$ & $\begin{array}{c}32.8 \\
7\end{array}$ & $\begin{array}{l}0 . \\
60\end{array}$ & $\begin{array}{c}1.8 \\
2\end{array}$ \\
\hline & $46 s$ & $\begin{array}{c}>34 \\
<=36\end{array}$ & $\begin{array}{l}5 . \\
3\end{array}$ & $\begin{array}{l}35 . \\
45\end{array}$ & $\begin{array}{c}0.8 \\
0\end{array}$ & $\begin{array}{c}2.2 \\
6\end{array}$ & 1. & $\begin{array}{l}34 . \\
63\end{array}$ & $\begin{array}{l}0 . \\
42\end{array}$ & \begin{tabular}{|c|}
1.2 \\
3
\end{tabular} & 2. & $\begin{array}{l}34 . \\
96\end{array}$ & $\begin{array}{c}0.5 \\
6\end{array}$ & \begin{tabular}{|c|}
1.5 \\
9
\end{tabular} & 2. & $\begin{array}{l}35 . \\
02\end{array}$ & $\begin{array}{c}0.6 \\
1\end{array}$ & $\begin{array}{c}1.7 \\
3\end{array}$ & 6. & $\begin{array}{c}35.0 \\
7\end{array}$ & $\begin{array}{l}\mathbf{0 .} \\
52\end{array}$ & $\begin{array}{c}1.4 \\
8\end{array}$ \\
\hline & $44 s$ & $\begin{array}{l}>36 \\
<=38 \\
\end{array}$ & 1. & $\begin{array}{l}37 . \\
65\end{array}$ & $\begin{array}{c}0.2 \\
2\end{array}$ & $\begin{array}{c}0.5 \\
8\end{array}$ & $\begin{array}{l}1 . \\
8\end{array}$ & $\begin{array}{l}37 . \\
21\end{array}$ & $\begin{array}{l}0 . \\
62\end{array}$ & $\begin{array}{c}1.6 \\
7\end{array}$ & 1. & \begin{tabular}{|l|}
36. \\
96
\end{tabular} & \begin{tabular}{|c|}
0.6 \\
1
\end{tabular} & \begin{tabular}{|c|}
1.6 \\
5
\end{tabular} & $\begin{array}{l}2 . \\
3\end{array}$ & $\begin{array}{l}37 . \\
\mathbf{0 2}\end{array}$ & $\begin{array}{c}0.6 \\
3 \\
\end{array}$ & $\begin{array}{c}1.7 \\
0 \\
\end{array}$ & 5. & $\begin{array}{c}36.5 \\
9\end{array}$ & $\begin{array}{l}\text { 0. } \\
58\end{array}$ & $\begin{array}{c}1.5 \\
9 \\
\end{array}$ \\
\hline & 40s & $\begin{array}{c}>38 \\
<=40\end{array}$ & 2. & $\begin{array}{l}38 . \\
96\end{array}$ & $\begin{array}{c}0.6 \\
1\end{array}$ & $\begin{array}{c}1.5 \\
8\end{array}$ & 1. & $\begin{array}{l}39 . \\
23\end{array}$ & $\begin{array}{l}0 . \\
73\end{array}$ & $\begin{array}{c}1.8 \\
7\end{array}$ & 1. & $\begin{array}{l}39 . \\
10\end{array}$ & $\begin{array}{c}0.6 \\
9\end{array}$ & $\begin{array}{c}1.7 \\
7\end{array}$ & 2. & $\begin{array}{l}38 . \\
77\end{array}$ & $\begin{array}{c}0.5 \\
7\end{array}$ & $\begin{array}{c}1.4 \\
8\end{array}$ & $\begin{array}{l}3 . \\
8\end{array}$ & $\begin{array}{c}39.0 \\
0\end{array}$ & $\begin{array}{l}0 . \\
62\end{array}$ & $\begin{array}{c}1.6 \\
0\end{array}$ \\
\hline & $36 s$ & $\begin{array}{c}>40 \\
<=42\end{array}$ & 7. & $\begin{array}{l}40 . \\
90\end{array}$ & \begin{tabular}{|c|}
0.6 \\
4
\end{tabular} & $\begin{array}{c}1.5 \\
6\end{array}$ & 1. & $\begin{array}{l}41 . \\
18\end{array}$ & $\begin{array}{l}0 . \\
79\end{array}$ & $\begin{array}{c}1.9 \\
1\end{array}$ & $\begin{array}{l}1 . \\
8\end{array}$ & $\begin{array}{l}41 . \\
03\end{array}$ & $\begin{array}{c}0.5 \\
9\end{array}$ & \begin{tabular}{|c|}
1.4 \\
5
\end{tabular} & 1. & \begin{tabular}{|l|}
41. \\
17
\end{tabular} & $\begin{array}{c}0.6 \\
5\end{array}$ & $\begin{array}{c}1.5 \\
7\end{array}$ & $\begin{array}{l}3 . \\
3\end{array}$ & $\begin{array}{c}40.9 \\
7\end{array}$ & $\begin{array}{l}0 . \\
63\end{array}$ & $\begin{array}{c}1.5 \\
3\end{array}$ \\
\hline $\begin{array}{c}\text { Ver } \\
\text { y } \\
\text { coar } \\
\text { se }\end{array}$ & $\begin{array}{c}\text { Coa } \\
\text { rser } \\
\text { than } \\
\mathbf{3 6 s}\end{array}$ & $>42$ & $\begin{array}{l}13 \\
.5\end{array}$ & $\begin{array}{l}58 . \\
99\end{array}$ & $\begin{array}{l}17 . \\
41\end{array}$ & 29. & 9. & $\begin{array}{l}53 . \\
23\end{array}$ & $\begin{array}{l}9 . \\
81\end{array}$ & $\begin{array}{l}18 . \\
43\end{array}$ & $\begin{array}{l}14 \\
.2\end{array}$ & \begin{tabular}{|l|}
53. \\
74
\end{tabular} & 11. & $\begin{array}{l}21 . \\
14\end{array}$ & $\begin{array}{l}14 \\
.6\end{array}$ & \begin{tabular}{|l|}
56. \\
83
\end{tabular} & 12. & 22. & 7. & $\begin{array}{c}50.5 \\
2\end{array}$ & $\begin{array}{l}10 \\
.8 \\
6\end{array}$ & $\begin{array}{c}21.5 \\
0\end{array}$ \\
\hline
\end{tabular}

+ obtained from Mathis and Faris (2007)

* This classification approximately matches the grades of the spinning count system. 
$\%$ percentage were calculated out the total number of observations per treatment.

$\mathrm{M}$, mean of fibre diameters.

$\mathrm{SD}$, standard deviation of the mean.

$\mathrm{CV}$, the coefficient of variation.

Percentages of wool fibres with diameters larger than the means $(30.09,25.28,27.56,28.8$ and $29.62 \mu \mathrm{m})$ were 34.7 , $30.9,33.3,38.6$ and $43.3 \%$ in control, ZADO $6 \mathrm{mg}$ and $10 \mathrm{mg}$, ZAD $6 \mathrm{mg}$ and 10mg, respectively. There were 13.5 , $9.1,14.2,14.6$ and $7.8 \%$ of fibres with average diameters equal to $58.99,53.23,53.74,56.83$ and $50.52 \mu \mathrm{m}$ coupled with markedly higher coefficients of variation accounting for 29.51, 18.43, 21.14, 22.31 and 21.50 for control, ZADO $6 \mathrm{mg}$ and $10 \mathrm{mg}$, ZAD $6 \mathrm{mg}$ and $10 \mathrm{mg}$, respectively. These wool characteristics are considered of poor quality (Mathis and Faris, 2007). Based on spinning count system, less hanks of yarn could be spun of this type of coarse wool. Naylor (1997) noted that the coefficient of variation increase as the number of coarse fibre increase. Unexpectedly, high coefficients of variation were obtained for fibres with means less than $10 \mu \mathrm{m}$, accounting for 12.37 and 26.65 in control and ZADO $10 \mathrm{mg}$, respectively. Decreasing fibre diameter is the most effective way to reduce the coarse fibre content. Meanwhile, reducing coefficient of variation will also reduce the number of coarse fibres, which improves comfort of wool garments.

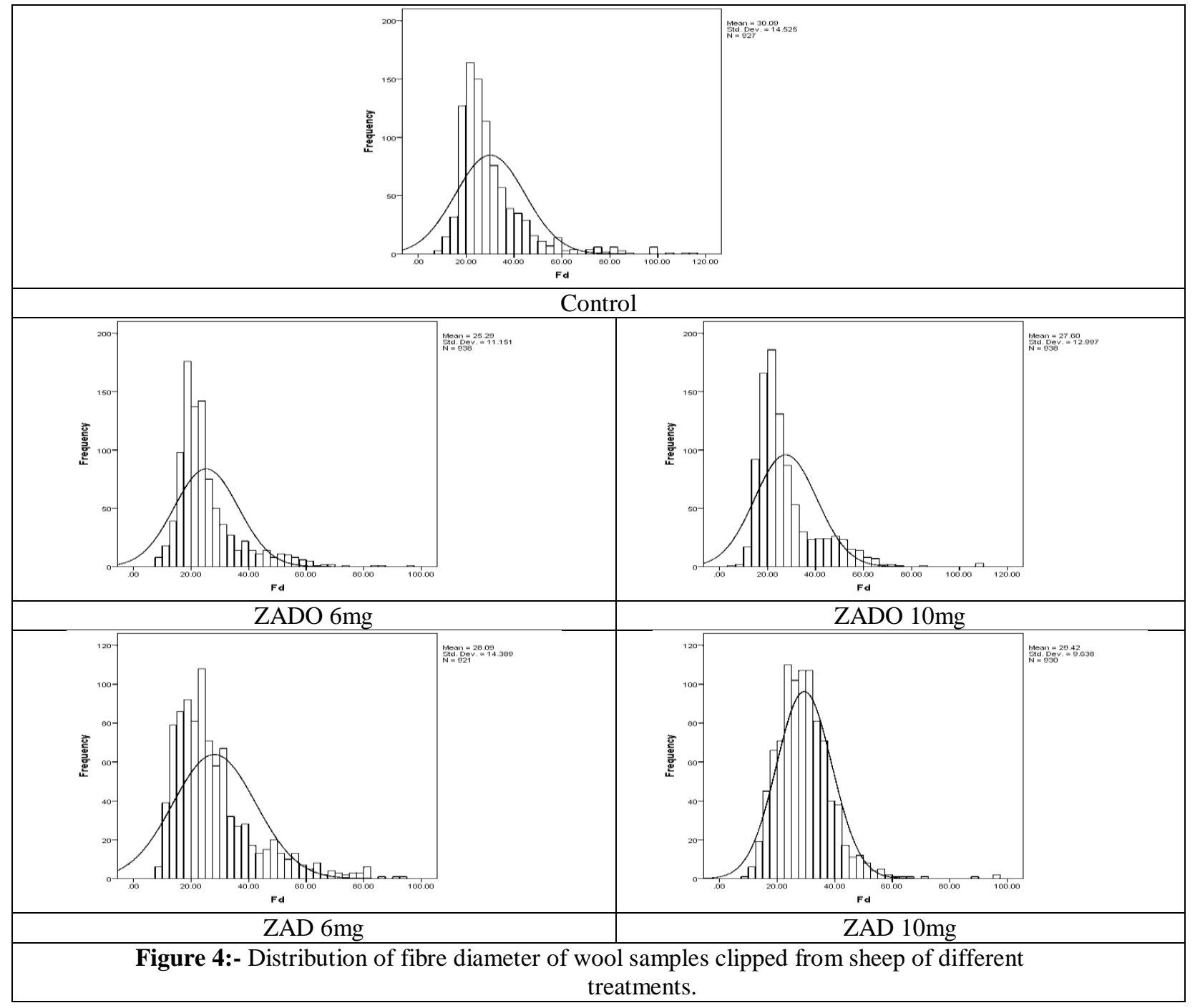

Distribution of fibre diameter is illustrated in Figure (4). Obviously showed higher percentage of coarse fibres, i.e. wool with fiber diameter higher than mean. There was great variation among diameters of fibres sampled. The coefficients of variation of fibre diameter were 48, 44, 47, 51 and 38\% in control, ZADO 6mg and 10mg, ZAD 6mg 
and 10mg, respectively. This variation may be due to the higher percentages of coarse fibres as indicated from Table (6).

\section{Conclusion:-}

It was concluded that compared with the control group, Both Zad and Zado with dose of 10 mg tended to increase the external, internal and fiber diameter of both primary and secondary follicles, as well as Carbohydrates concentration. The same effect was found with wool staple length and medullated fiber percent. On the other hand opposite trend was found for the effect of Both Zad and Zado with dose of $10 \mathrm{mg}$ on proteins concentration in both outer and inner root sheath. Results also declared that Zado increased kemp\%, while Zad tended to decrease it and the opposite trend was found with fine fibre $\%$.

\section{References:-}

1. Abd El-Aziz, F.R. (2007). BiologicalTreatment of Agriculture By- Products and theirEffect on Lambs Performance. M.Sc. Thesis, Fac. Agric., Ain-shamsUniv., Egypt, 73p.

2. Abdou, A.S., Hekal, S.A., Badawy, N.S. and Ramadan, W.A. (2016). Responses of skin and coat fibres in Barki ewes to the nutrition on salt plants and propionibacteria under the arid conditions.Egy. J. Anim. Prod. (2016) 53(3):169-179.

3. Abdelaziz, N.M.; El-Gabbas, H. M.; Abdelsalam, M.M and Al-Bitar, E.M (2000). The responses of some factors and nutritional stresses on objective and subjective wool traits of some Egyptian breeds of sheep. Proc. $3^{\text {rd }}$ All Africa

4. Abdel-Salam, A.M.; Zeitoun, M.M. and Abdelsalam, M.M. (2014). Effect of Synbiotic Supplementation on Growth Performance, Blood Metabolites, Insulin and Testosterone and Wool Traits of Growing Lambs. Journal of Biological Sciences Volume 14, Number 4, 292-298

5. AboBaker, S. (2012). Nutrional studies on goats fed treated straw under North Sinai conditions.Ph. D. Thesis.Cairo University.

6. Adesogan, A.T. (2005). Improving forage quality and animal performance with fibrolytic enzymes. In: Florida Rum. Nutr.Symp.pp. 91-109.

7. Almustafa M. Saria (2013). Alleviation of heat stress and improvement of productive performance of sheep under hot climatic conditions.Ph. D. thesis. Fac. Agric., Ain Shams Univ., Egypt.

8. Aziz, A. A. (2009). Effect of Feeding Olive Tree Pruning By-Products in Sinai on Sheep Performance. Ph. D. Thesis, Fac. Agric., Ain Shams Univ., Egypt, 264 p.

9. Barker, J.R. (1958). Principles of Biological Technique.London, Methuen, New York, John Wiley, Bancroft. J. D.

10. Beauchemin, K.A., Rode, L.M. (1996). Use of feed enzymes in ruminant nutrition. In: Rode, L.M. (Ed.), Proc. Can. Soc. Anim. Sci. Lethbridge, AB, Canada, pp. 103-130

11. Chapman, D.M. (1975). Dichromation of bromophenol blue with an improvement in the mercuric bromophenol blue technique for protein. Stain Technology., 50: 25-30.Conf. Anim. Agric. and $11^{\text {th }}$ Conf. Egyptian Soc. Animal Proc. Alexandria, Egypt. 6-9 November, 2000:729-736.

12. Dawson, K.A., Tricarico, J.M. (1999). The use of exogenous fibrolytic enzymes to enhance microbial activities in the rumen and performance of ruminant animals. In: Proc. $15^{\text {th }}$ Annual Symp. Biotech. Feed Industry, Loughborough, Leics, UK, pp. 303-312.

13. Groot, G.J.J.B. (1992). The effect of coefficient of variation of fibre diameter in wool tops on yarn and fabric properties. Wool Tech. Sheep Breed., 40(2): 60-64.

14. Doyle, P. T., Plaisted, T. W. and Love, R. A. (1995). Supplementary feeding pattern and rate of liveweight gain in winter-spring affect wool production of young Merino sheep on south coast of Western Australia. Australian. Journal of Experimental Agriculture, 35(8): 1093-1100. (Nutritional Abst. And Reviews, (1995), 66 (6):2743.

15. Drury, R.A.B. and Wallington, E.A. (1980). Carleton's Histological Technique. $5^{\text {th }}$ Ed. Oxford University Press. Oxford, UK., 520.

16. Eun, J.-S., Beauchemin, K.A., Schulze, H. (2007). Use of an in vitro fermentation bioassay to evaluate improvements in degradation of alfalfa hay. Anim. Feed Sci. Technol. 35, 315-328.

17. Feng, P., Hunt, C.W., Pritchard, G.T., Julien, W.E. (1996). Effect of enzyme preparations on in situ and in vitro degradation and in vivo digestive characteristics of mature cool-season grass forage in beef steers. J. Anim. Sci. 74, 1349-1357. 
18. Feng, P., Hunt, C.W., Pritchard, G.T., Julien, W.E. (1996). Effect of enzyme preparations on in situ and in vitro degradation and in vivo digestive characteristics of mature cool-season grass forage in beef steers. J. Anim. Sci. 74, 1349-1357.

19. Gado, H.M., Salem, A.Z.M., Robinson, P.H. and Hassan, M. (2009). Influence of of exogenous enzymes on nutrient digestibility, extent of ruminal fermentation as well as milk production and composition in dairy cows. Anim. Feed Sci. Tech. 154, 36-46.

20. Gado, H. (1997). Effect of enzymatic treatments for poor quality roughages on fiber digestibility and nitrogen metabolism inBaladi goats.Egyptian J. Nutr.Feeds, 50-56 (special issue).

21. Gado, H.M., Metwally, H.M., Soliman, H., Basiony, A.Z.L., El Galil, E.R. (2007). Enzymatic treatments of bagasse by different sources of cellulase enzymes. In: The 11th Conf. Animal Nutr., Al-Aqsor-Aswan, Egypt on 2 November, 13-18, vol. 10, p. 607.

22. Gado, H.M., Salem, A.Z.M. (2008). Influence of exogenous enzymes from anaerobic source on growth performance, digestibility, ruminal fermentation and blood metabolites in lambs fed of orange pulp silage in total mixed ration. In: 59th Annual Meeting of the European Association for Animal Production, Vilnius, Lithuania, August 24-27, p. 228 (Abstract).

23. Helal, A. and Fayed, A. M. (2013). Wool characteristics of sheep fed on halophyte plants ensiled by some biological treatments. Proceedings Book of $4^{\text {th }}$ International Scientific Conference on Small Ruminant Development.

24. Jafari, A., Edriss, M.A., Alikhani, M. and Emtiazi, G. (2005). Effected of treated wheat straw with exogenous fibre degrading enzymes on wool characteristics of ewe lambs. Pakistan J. Nutrition 4(5): 321-326.

25. Kearl, L. C. (1982). Nutrient requirements of ruminants in developing countries. Int. Feedstuffs Inst., Utah, U S A.

26. Krueger, N.A., Adesogan, A.T., Staples, C.R., Krueger, W.K., Kim, S.C., Littell, R.C., Sollenberger, L.E. (2008). Effect of method applying fibrolytic enzymes or ammonia to Bermuda grass hay on feed intake, digestion, and growth of beef steers. J. Anim.Sci. 86, 882-889.

27. Lamb, P.R. (1992). The effect of fibre diameter distribution on yarn properties. Wool Tech. Sheep Breed. 40(2): 65-68.

28. Mathis, C.P. and Faris, B. (2007). Wool grades. Guide B-409. Cooperative Extension Service, college of Agriculture and Home Economics, New Mercico start University [www. Cahe.Mmsu.Edu]

29. McGregor B.A. (1988). Effects of different nutrional regimes on the productivity of austrliancashmer goats and the partioning of nutrients between cashmer and hair growth. Aust. J. of Exp. agric., 28: 459-467.

30. Mc-Manus, J.P.A. and Cason, J.E. (1950). Carbohydrate histochemistry studied by acetylation techniques periodic acid method. J. Exp. Med., 91: 651.

31. Miller, D.R., Elliott, R. and Norton, B.W. (2008). Effects of an exogenous enzyme, Roxazyme ${ }^{\circledR}$ G2 liquid, on digestion and utilization of barley and sorghum grain-based diet by ewe lambs. Animal feed science and Tech., 140(1), 90-109.

32. Montegana, W. (1956). The structure and function of the skin.Academic press, New York. 174.

33. Naylor, G. R. S. (1997). The implicit value of fibre diameter distribution assigned by the airflow technique. Wool Tech. Sheep Breed., 45(4): 221-226.

34. Naylor, G.R.S., Phillips, D.G. and Veitch. (1995). The relative importance of mean diameter and coefficient of variation of sale lots in determining the potential skin comfort of wool fabrics. Wool Tech. Sheep Breed., 43(1): 69-82.

35. Naylor, G. R. S. (2000). Adding Value to Top: Measurement of the Diameter Characteristics of Fibre ends as a Tool for Improved Prediction of Fabric Skin Comfort." (CTF01).

36. Nsereko, V.L., Beauchemin, K.A., Morgavi, D.P., Rode, L.M., Furtado, A.F., McAllister, T.A., Iwaasa, A.D., Yang, W.Z., Wang, Y. (2002). Effect of a fibrolytic enzyme preparation from Trichoderma longibrachiatum on the rumen microbial population of dairy cows. Can. J. Microbiol. 48, 14-20.

37. Onder, E., Kalaoglu, F., and Ozipek, B. (2003). Influence of Varying Structural Parameters on the Properties of 50/50 Wool/ Polyester Blended Fabrics, Textile Res. J. 73, 854-860.

38. Parmar, M.L., Sinha, R.D. Parasad, G. and Prasad, J. (1988). Histochemical studies on hair follicles and sebaceous and sweat gland in goat. Indian Journal of Animal Sciences 58 (7): 789-791.

39. Phillips, A., Salkoff, L., Kelly, L. (1991). Molecular characterization of a second Drosophila glutamate decarboxylase gene. Greenspan, Palka, 97.

40. Raghuvansi, S.K.S., Prasad R., Mishra, A.S. chaturvedi, O.H. Tripathi, M.K. Misra, A.K. Saraswat B.L. and Jakhmola, R.C.. (2007). Effect of inclusion of tree leaves in feed on nutrient utilization and rumen fermentation in sheep. Biores. Technol., 98:511-517. 
41. Reis, P.J., Tunks, D.A. and Munro, S.G. (1992). Effects of abomasal protein and energy supply on wool growth in Merino sheep. Crop and Pasture Science, 43(6),1353-1356.

42. Salem, A. Z. M., Hassan, A. A., Kalil, M. S., Yacout, M. H. and Gado, H. (2007). Feed intake, digestibility coefficients, nitrogen utilization and loss of secondary compounds in whole gastrointestinal tract in sheep fed Atriplexhalimusfoliages in presence of ZADO as direct fed micrl. The $12^{\text {th }}$ Seminar of the FAO - CIHEAM Sub-Network on Sheep and Goat Nutritional.: Nutritional and foraging ecology of sheep and goats Thessaloniki, Greece, 2007 (Cited from Kholif, 2008).

43. SAS, (2004). Statistical Analysis System Institute, SAS User's Guide Statistics, SAS Institute Inc., Cary, NC.

44. Scobie, D. R., Bray, A. R. and Merrick, N. C. (1998). Medullation and average fiber diameter vary independently in the wool of Romney sheep. N. Z. J. Agric, Res., 41:101-110.

45. Sharaf El-din, M.A. and Ghoneim, K.E. (1963). Some non-genetic factors affecting wool characters of Fleisch Merino sheep.2nd Conf. U. A. R. Anim. Prod.

46. Soliman, M.S. (2006). Utilization of peanut hay in ruminant feeding. Ph.D. Thesis. Alexandria University, Alexandria, Egypt vivo digestive characteristics of mature cool-season grass forage in beef steers. J. Anim. Sci. 74, 1349-1357.

47. Wilson, J. F. (1940). Row wool and its manufacture. J. Text. Inst., 13: 23.

48. Zen (2012). (Blue edition) Carl Zeiss MicroImaging GmbH. 07740 Jena, Deutschland, BioSciences | Location Göttingen, P.O.B. 4041, 37030 Göttingen, Germany. 